\title{
TUKEVA uUdistaa koulutusta
}

\author{
Juhani Nieminen
}

\author{
TUKEVA on valtakunnallinen koulutus- ja tutkimus- \\ hanke, jonka avulla ammatillisessa aikuiskoulutuksessa \\ työskentelevät voivat työnsä ohessa kouluttaa itseään \\ lisää ja nostaa ammattitaitoaan. Hanke käynnistyi \\ kansallisin voimin, mutta nyt sen takana on myös \\ Euroopan sosiaalirahasto ESR. Koordinoijana on \\ Ammatillisten aikuiskoulutuskeskusten liiton yhteydessä \\ toimiva Aike oy.
}

$\mathrm{T}$

UKEVA on lyhennys sanoista tutkimus, kehitys ja valmennus. Projekti on jatkoa ammatillisten aikuiskoulutuksen opettajille suunnattua kehitysohjelmaa, KEHOa, jonka päätöstilaisuudessa kesällä 1998 TUKEVA ensi kertaa esiteltiin.

KEHO tarjosi opettajille erilaisia parin opintoviikon laajuisia täsmävälineitä käytännön töihin. KEHON jatkoksi haluttiin luoda mittava kokonaisuus poikkitieteellistä koulutustarjontaa, joka antaisi työssä käyville aikuiskouluttajille mahdollisuuden päivittää käytännön osaamisensa sekä kohottaa akateemista tasoaan vähintään yhtä astetta korkeammalle. Yleisen osaamisen tason kohottamisen todettiin myös nostavan ammatillisen aikuiskoulutuksen statusta ja parantavan sen imua ja kilpailukykyä koulutusmarkkinoilla.

$\mathrm{T}$ UKEVAn koulutusohjelma toteutetaan yliopistojen ja ammattikorkeakoulujen kautta niiden tutkintovaatimusten tasosta tinkimättä. TUKEVAn opiskelijat ovatkin tietoisia siitä, että heiltä vaadittu työmäärä vastaa perusopiskelijoiden työmäärää ja heihin kohdistuvat vaatimukset ovat vähintäänkin samalla tasolla. Tuloksiin kuitenkin pyritään uusia, joustavia opetusjärjestelyjä ja menetelmiä käyttäen, jotta työn ohessa tapahtuva opiskelu olisi mahdollista. Opiskelun mielekkyyttä ja tuottavuutta pyritään parantamaan kytkemällä harjoitukset ja raportit mahdollisimman laajalti opiskelijoiden työtehtäviin ja arkitodellisuuteen.

$\mathrm{N}$ imensä mukaisesti TUKEVAn keskeisimpiin alueisiin kuuluvat tutkimus ja kehittäminen. Kehittämisen tavoitteiksi on projektissa määritelty mm. tarjottavan opetuksen monimuotoistaminen ja -välineistäminen, virtuaalisten oppimisympäristöjen luominen, uusien työelämäyhteyksien rakentaminen ja hyväksikäyttö oppimisessa sekä eri oppilaitostasojen ja elinkeinoelämän verkottuminen. Kaiken kaikkiaan tutkimus- ja kehityskohteet kattavat sekä opettajan työn perinteiset että uudet ulottuvuudet. Siten koulutus ja sen avulla saavutettava oppiminen nähdäänkin TUKEVAssa paljolti valmennuksena, jonka avulla ammatillinen aikuisopettaja voi entistä paremmin suoriutua työstään muuttuvassa toimintaympäristössä.

$\mathrm{V}$ aikka TUKEVA tuli selkeään tarpeeseen ja vaikka sillä alusta alkaen oli hyviä ja sitoutuneita tukijoita tärkeillä päättäjätasoilla, oli mittavan projektin käynnistys varsin vaikeaa. Oppilaitoksilla, joiden tehtävä oli tuottaa projektissa 
tarvittavaa koulutusta, ei ollut mahdollisuuksia eikä halua sitoutua pitkäaikaiseen hankkeeseen ennen rahoituksen varmistumista. Osa rahoituksesta saatiin vuosina 1998-99 kuntoon kansallisin voimin. Kiitoksen tästä ansaitsevat opetushallituksen ja -ministeriön asiaa hoitaneet virkamiehet, jotka omissa organisaatioissaan veivät uutta hanketta eteenpäin. Kansallisella rahoituksella päästiin käynnistämään TUKEVAn ammattikorkeakouluosuus, joka sisälsi eri alojen ammattikorkeakoulututkintoihin johtavaa koulutusta sekä opettajan työn kehittämisohjelman, OTKOn, joka on laajuudeltaan, sisällöiltään ja rakenteeltaan samanlainen kuin ammatillisten opettajakorkeakoulujen opettajankoulutusohjelmat.

Kansallisella rahoituksella voitiin toteuttaa myös joitakin yksittäisiä kokonaisuuksia yliopistoopinnoista mm. kasvatustieteissä. Tutkintotavoitteisten yliopisto-opintojen mittavaa käynnistystä ei kuitenkaan voitu aloittaa ennen pidemmän aikajänteen rahoituksen varmistumista. Vuoden 2000 alussa jätettiin TUKEVA-rahoitushakemukset Euroopan sosiaalirahastolle (ESR), ja ensimmäinen myönteinen ESR-päätös saatiin elokuussa. Vasta se varsinaisesti mahdollisti TUKEVAn yliopisto-opintojen tutkintoihin johtavan osuuden käynnistämisen täydessä mitassa. Päätös koski koko alue kolmosta eli Etelä- ja Länsi-Suomen läänejä. Se oli erittäin ratkaiseva, koska sen ansiosta päästiin aloittamaan noin 80 prosenttia alkuaan kaavaillusta TUKEVAn yliopistotason koulutuksesta.

Itä- ja Pohjois-Suomen (alue 1) osalta päätöksentekomekanismi poikkeaa kolmosalueen vastaavasta ja ratkaisut tehdään paljolti maakunnissa. Tämä on hidastanut prosessia. Vaikka Itä- ja Pohjois-Suomen päätökset koskevat vain noin 20 prosenttia kaikista potentiaalisista TUKEVAopiskelijoista, on niiden merkitys alueellisen tasaarvon kannalta erittäin merkittävä. Lisäksi koulutustarve on Itä- ja Pohjois-Suomessa kaikkein suurin, koska koulutustaso siellä on kolmosaluetta alhaisempi. Nopeat, myönteiset ratkaisut maakunnissa olisivatkin TUKEVAn ja ennen muuta ykkösalueen opiskelijoiden kannalta toivottavia.

\section{Erilaisia toimijoita ja toimintamalleja}

E des TUKEVAn kaltainen hanke ei voi tarjota aikkea kaikille. Siksi projektin koordinaattoriksi nimitetty Aike Oy selvitti eri alojen aikuiskoulutuskeskusten henkilöstön yliopistollisia koulutustarpeita ennen koulutuksen suunnittelua ja käynnistystä. Selvityksen tuloksena todettiin selkeästi kolme muita kysytympää alaa: kauppatieteet, kasvatustieteet sekä tekniikka ja liikenne. Resurssit päätettiin kohdistaa näiden alojen koulutukseen. Korkeakoulujen kanssa käytyjen neuvottelujen tuloksena valittiin eri aloille päätoimijat, jotka ottivat vastatakseen alan koulutuksen toteuttamisesta sovitulla tavalla.

$\mathrm{T}$ ekniikassa koulutuksen koordinoinnista ja kehittämisestä vastaa Oulun yliopisto, ja itse koulutusta on toteuttamassa yksiköitä kaikista teknillisistä korkeakouluista. Tuotantotalouden koulutuksesta vastaa Teknillisen korkeakoulun Lahden keskus yhdessä Lappeenrannan teknillisen korkeakoulun kanssa. Tampereen teknillisen korkeakoulun täydennyskoulutuskeskus Edutech puolestaan toteuttaa koneteollisuuden tuotantotekniikan ohjelman ja Porin yksikkö vastaa tietotekniikan täydennyskoulutusohjelmasta. TUKEVA-ohjelman aikana mukaan otettavat yhteensä 100 opisto- tai AMK-insinööriä pyrkivät suorittamaan diplomi-insinöörin (DI, 180 ov) tutkintoon tarvittavat opinnot. Myös tekniikan alan jatkotutkintoihin tarvittavat opinnot tai niiden osia voi suorittaa TUKEVAssa. Projektin tavoitteeksi on tekniikan osalta kirjattu 75 suoritettua tutkintoa vastaavat opinnot. Kun tekniikan alalla ei ainakaan toistaiseksi ole välitutkintoa, voi- 
daan tavoitetta pitää vaativana. Insinöörin tutkinnosta luetaan opiskelijoille hyväksi 60 opintoviikkoa, mikä jättää diplomitöineen opiskelijan urakaksi vielä 120 opintoviikon työmäärän.

$\mathrm{T}_{\mathrm{s}}$ ekniikan ohjelmat ovat TUKEVAn korkeakouluohjelmista yhtenäisimmät. Sivuaineissa on ohjelmissa kuitenkin TUKEVA -hengen mukaista pelivaraa. Koska tekniikan ohjelmat ovat varsin vaativia ja kuhunkin ohjelmaan mahtuu vain 33 opiskelijaa, kaikki opiskelijat on valittu pääsykokeiden kautta. Haut ovat päättyneet ja hakijoita kaikkiin kolmeen ohjelmaan oli runsaasti. Esimerkiksi tuotantotaloutta opiskelemaan haluavista vain vajaa puolet mahtui mukaan. Ohjelmista koneteollisuuden tuotantotekniikan koulutus käynnistyy vielä tänä vuonna, muut ohjelmat alkavat ensi vuoden alussa.

$\mathrm{K}^{2}$ auppatieteiden koulutusta koordinoi ja toeuttaa Jyväskylän yliopisto. Yhteensä kauppatieteitä opiskelee TUKEVAn avulla noin 150 opiskelijaa. Osalla on ensiaskeleena opistotasoisen koulutuksen nostaminen alemmaksi yliopistolliseksi tutkinnoksi (kauppatieteen kandidaatti, KTK, 120 ov), jotkut taas päivittävät vanhaa ekonomi-tutkintoaan, uudempaa KTK-tutkintoa tai muuta soveltuvaa koulutusta suoraan kauppatieteen maisterin (KTM, 160 ov) tasolle. Myös tieteellisiin jatkotutkintoihin johtavaa koulutusta suorittavia on joukossa.

Jyväskylän yliopisto toteuttaa ohjelmia joustavasti, ja eri tasoille pääsee varsin erilaisista taustoista tulevia opiskelijoita. Heterogeeninen aines teettää yliopistolla runsaasti järjestelytyötä, mutta on toisaalta kiinnostava tehtävä. Yliopisto tekee TUKEVAn yhteydessä myös merkittävää yli tieteenalojen ulottuvaa virtuaaliopetuksen kehittämistyötä Metodix-ohjaus- ja seurantatyökalua rakentavan yhteistyöyrityksen kanssa.

$\mathrm{K}^{2}$ auppatieteissä alustavat tutkintoon johtavia pintoja suorittavien lukumäärätavoitteet noudattelevat tekniikan tavoitteita. Kauppatieteen opiskelijoiden lähtötaso on vaihtelevampi, mutta alalla oleva alempi korkeakoulututkinto antaa toisaalta mahdollisuuden siihen, että yksittäinen opiskelija voi joissakin tapauksissa suo- rittaa projektin aikana ensin alempaan (KTK) ja sen perään vielä ylempään (KTM) korkeakoulututkintoon johtavia kokonaisuuksia.

【 ukumääräisesti suurin joukko TUKEVAn yli¿pisto-opiskelijoista on kasvatustieteen tutkintoihin johtavissa ohjelmissa. Kun primäärikohderyhmänä ovat opettajat, tämä on varsin luonnollista. Tampereen yliopiston kasvatustieteiden tiedekunta ja erityisesti sen Hämeenlinnassa sijaitseva ammattikasvatuksen tutkimus- ja koulutuskeskus vastaavat kasvatustieteellisen koulutuksen toteutuksesta. Tampereen yliopiston tavoitteena on kuitenkin pyrkiä kytkemään myös muita kasvatustieteellistä koulutusta tarjoavia yliopistoja hankkeeseen erilaisia kokonaisuuksia tarjoavina alihankkijoina.

Kasvatustieteen opiskelijoiden tutkintotavoitteet ovat samantyyppisiä kuin kauppatieteissä, eli kasvatustieteiden kandidaatti (KK, 120 ov) on ensimmäinen porras, jolle opiskelija voi pyrkiä TUKEVA-opintojen kautta. KK-tutkinnon tai riittävästi kasvatustieteellisiä opintoja koonneet muita alempia korkeakoulututkintoja tai ammattikorkeakoulututkintoja suorittaneet voivat hakea opiskelemaan kasvatustieteen maisterin (KM, 160 ov) tutkintoon kuuluvia kokonaisuuksia. Kasvatustieteissä on myös huomattava joukko jatko-opiskelijoita, joilla on tilaisuus suorittaa TUKEVAn kautta kasvatustieteen lisensiaatin (KL) tutkinnon opintokokonaisuuksia.

TUKEVAn kasvatustieteen opinnot ovat ammattikasvatuspainotteisia, mikä antaa mahdollisuuden varsin laajaan sivuaineiden kirjoon. Myös opiskelijoiden aiempien yliopistollisten opintosuoritusten ja opistotasoisten tutkintojen yhden- ja oikeudenmukaisen hyväksilukemisjärjestelmän luominen on ollut Tampereen yliopiston tehtävänä. Tampereen yliopisto tekee merkittävää kehitystyötä myös rakentamalla TUKEVAa varten uusia, tämän päivän tarpeita palvelevia arvosanakokonaisuuksia, joita myöhemmin voidaan tarjota myös perusopiskelijoille. Jo nyt on rakennettu ja toteutettu ammattikasvatuksen approbatur ja kehitettävinä ovat mm. ympäristökasvatuksen, kansainvälistymiskasvatuksen ja viestintäkasvatuksen arvosanakokonaisuudet. 


\section{Ammat tikorkeakouluopiskelu TUKEVAssa}

$\mathrm{M}$ erkittävä osa TUKEVAn opiskelijoista päiittää osaamistaan ammattikorkeakouluissa. Päätoimijoina ovat Hämeen ja Turun ammattikorkeakoulut, jotka ovat kytkeneet alihankkijoina mukaan maan muita ammattikorkeakouluja. Opiskelijat tavoittelevat TUKEVA-opintojen kautta mm. insinööri AMKn, tradenomin ja restonomin tutkintoa. Koska ammattikorkeakoulutasoisen TUKEVA-koulutuksen rahoitus on kokonaan kansallista, on projekti edennyt tällä sektorilla pidemmälle kuin yliopistokoulutuksessa. TUKEVA on tarjonnut mukana oleville ammattikorkeakouluopiskelijoille tien oman alan uusimman tiedon ja taitojen äärelle. Se on myös antanut mukana oleville ammattikorkeakouluille haastavan, mutta tulevaisuutta ajatellen oivallisen tavan kehittää omaa koulutustarjontaansa vastaamaan pitkän työkokemuksen hankkineiden aikuisten työn ohessa tapahtuvaa opiskelua.

\begin{abstract}
$\mathrm{A}$ mmatissa toimiville aikuiskoulutuskeskusten opettajille suunnattu OTKO-koulutus on 35 opintoviikon pituinen ohjelma, joka tasollisesti ja sisältöjen puolesta on ammatillista opettajankoulutusta tarjoavien opettajakorkeakoulujen koulutusohjelmien mukainen. TUKEVAssa OTKO on suurin kokonaisuus ja kaikkiaan siihen on osallistunut noin 800 opettajaa. OTKOa toteuttamassa ovat olleet kaikki ammatilliset opettajakorkeakoulut eli Helsingin Helia, Hämeenlinna, Jyväskylä, Oulu ja Tampere. Koordinoinnista on vastannut Hämeenlinnan opettajakorkeakoulu.
\end{abstract}

\section{TUKEVA on iso haaste kaikille}

$\mathrm{T}$ UKEVAn kaltainen hanke vaikuttaa muutenkin kuin pelkkien lukujen valossa voisi päätellä. Sen merkittävimmät vaikutukset näkyvät toivottavasti pitkälle tuleviin vuosiin mukanaolevien toimintaa laaja-alaisesti parantavina muutoksina niin toteuttaja- kuin opiskelijatasolla. Muutos voi pahimmillaan jäädä pinnalliseksi, mutta lähtökohtana on, että TUKEVA edellyttää aivan uudenlaista ennakkoluulottomuutta ja innovatiivista ajattelua sekä toteuttajilta että opis- kelijoilta. TUKEVA ei kuitenkaan ole mikään koulutuksen ihmelääke. Kuten kaikki opiskelu ja koulutuksen tuottaminen TUKEVA edellyttää kovaa työtä ja myös uhrauksia kaikilta mukanaolevilta. Lisäksi se vaatii tahtoa ja kykyä nähdä, että asiat voi tehdä toisin, kuin ennen on tehty, vaikka halu kulkea entisiä, turvallisilta tuntuvia uomia olisi kova. TUKEVA mittaakin omalta osaltaan eri tason toimijoiden ja mukana olevien opiskelijoiden kykyä vastata muutokseen, tarttua sen tarjoamiin mahdollisuuksiin ja selvitä uhkatekijöistä.

TUKEVAa ei olisi koskaan saatu käyntiin ilman lukuisten eri tahojen halua ja kykyä toimia yhdessä. Projektin edetessä yhteistyökyvyn merkitys korostuu, koska monet eteen tulevat ongelmat edellyttävät opiskelijoiden, toimijoiden ja projektin ohjauksesta vastaavien tahojen läheistä yhteistyötä.

TUKEVA-projekti noudattelee ESR-rahoituskausia. Projektia on tarkoitus jatkaa näillä näkymin vuoteen 2006, mutta hankkeen eteneminen ratkaisee, käykö näin. TUKEVAn tavoitteet ovat varsin korkealla. Onnistuessaan TUKEVA -projekti voi antaa sijoitetulle pääomalle todella hyvän koron. Se voi tuottaa koko maan tulevaisuuden kannalta merkittäviä koulutusinnovaatioita ja uusia toimintamalleja niin toimijoina oleviin yliopistoihin ja korkeakouluihin kuin opiskelijoina olevien opettajien oppilaitoksiin. TUKEVA voi myös toimia päänavaajana laajempiin kansallisiin ja kansainvälisiin projekteihin.

TUKEVA tuottaa joka tapauksessa suuren joukon sekä muodollisesti että käytännössä entistä pätevämpiä aikuiskouluttajia eri oppilaitoksiin. Se myös tarjoaa mukana oleville oppilaitoksille tilaisuuden kehittää omaa toimintaansa ja kokeilla erilaisia koulutusvaihtoehtoja. Näin se parantaa sekä oppilaitosten että niissä toimivien ihmisten mahdollisuuksia selviytyä turbulentissa toimintaympäristössä. TUKEVA antaa myös arvokasta kokemusta ja oppia kaikille mukanaolijoille tällaisissa yhteistoimintaa ja avoimuutta edellyttävissä suurissa hankkeissa piilevistä ongelmista ja niiden ratkaisemisesta. 